\title{
Analisis Pemanfaatan Internet di Pusat Pemerintahan Kabupaten Badung
}

\author{
I Made Rai Suarimbawa ${ }^{1}$, Linawati ${ }^{2}$, Nyoman Putra Sastra ${ }^{3}$
}

\begin{abstract}
Dishubkominfo as ICT implementing agency, currently serves internet connection of all SKPD in Badung Regency Government Center with bandwidth capacity of 200 Mbps and complaints about the stability and speed of internet access is still a lot going on, both from the internal use of SKPD or external from the community. This problem needs to be addressed by analyzing the characteristics of internet utilization traffic and user behavior in each SKPD so that bandwidth management policy will be right on target. This study aims to monitor and model characters from users using NetFlow and NFDUMP.

Based on the study results at Badung District Government Center, it was observed that TCP protocol has the highest level of network usage, followed by UDP protocol, and several other protocols. In terms of traffic sources, it is known that social media is the most frequently accessed site by the user. The results of this study can be used as a consideration in increasing the network bandwidth capacity and policies implemented in the Government Center of Badung Regency associated with internet access.
\end{abstract}

Intisari- Dishubkominfo sebagai instansi pelaksana TIK, saat ini melayani koneksi internet seluruh SKPD di Pusat Pemerintahan Kabupaten Badung dengan kapasitas bandwidth sebesar 200 Mbps dan keluhan akan stabilitas dan kecepatan akses internet masih banyak terjadi, baik dari internal penggunaan SKPD maupun eksternal dari masyarakat. Permasalahan ini perlu disikapi dengan melakukan analisis mengenai karakteristik trafik pemanfaatan internet dan user behavior di masing-masing SKPD sehingga kebijakan manajemen bandwidth akan tepat sasaran. Penelitian ini bertujuan untuk mengetahui karakteristik trafik pada pemanfaatan internet dan memodelkan karakter dari pengguna dengan menggunakan NetFlow dan NFDUMP.

Hasil penelitian menunjukan bahwa protokol TCP memiliki pringkat tertinggi dalam penggunaan jaringan, diikuti oleh protokol UDP, dan beberapa protokol lainnya. Dari sisi sumber trafik, diketahui bahwa media sosial adalah situs yang paling sering diakses oleh user. Hasil dari penelitian ini bisa digunakan sebagai bahan pertimbangan dalam peningkatan kapasitas bandwidth jaringan dan kebijakan yang diterapkan di Pusat Pemerintahan Kabupaten Badung terkait dengan akses internet.

Kata Kunci- Jaringan Pemerintah, Prilaku Pengguna Internet, Trafik Internet.

\section{Pendahuluan}

Penggunaan teknologi informasi komunikasi khususnya internet dalam membantu menyelesaikan pekerjaan secara

\footnotetext{
${ }^{\text {I} D i s h u b k o m i n f o ~ B a d u n g ~}{ }^{2,3}$ Dosen, Teknik Elektro Universitas Udayana, Jl.P.B. Sudirman, Denpasar, Bali, Indonesia 80114 (tlp: 0361-239599; fax: 0361-239599; e-mail: raisuarimbawa7@gmail.com linawati@unud.ac.id putra.sastra@unud.ac.id.
}

efektif dan efisien dalam suatu organisasi saat ini sudah menjadi kebutuhan yang mendasar. Hampir semua sektor menggunakan sumber daya teknologi informasi komunikasi, mulai dari sektor pemerintahan, pendidikan, industri, swasta, mulai tingkat pusat sampai tingkat daerah. Disektor pemerintahan, pembangunan dan penggunaan teknologi informasi komunikasi berbasis internet sering disebut dengan e-government (pemerintahan).

Perkembangan teknologi informasi dan Komunikasi (TIK) dari waktu ke waktu yang terus meningkat, mengakibatkan kebutuhan akan informasi secara cepat dan tepat menjadi sebuah tuntutan baru. Tuntutan tersebut juga terjadi di pemerintahan agar memberikan pelayanan publik secara efektif, efisien, transparan dan akuntabel. Dalam Instruksi Presiden Republik Indonesia Nomor 3 Tahun 2003, tentang Kebijakan dan Strategi Nasional Pengembangan $E$ Government diamanatkan pemerintah harus mampu memanfaatkan kemajuan teknologi informasi untuk meningkatkan kemampuan mengolah, mengelola, menyalurkan dan mendistribusikan informasi dan pelayanan publik. Dengan demikian pemerintah harus segera melaksanakan proses transformasi menuju e-government [1].

Dalam upaya mempercepat terwujudnya implementasi $e$ government keberadaan perangkat/infrastruktur jaringan komunikasi data merupakan komponen vital yang harus dimiliki disamping komponen penunjang lainnya. Implementasi dan pengembangan e-government harus ditunjang oleh infrastruktur Teknologi Informasi dan Komunikasi (TIK) yang kuat sebagai landasan berjalannya seluruh aplikasi yang terintegrasi dan handal. Pembangunan infrastruktur TIK memerlukan investasi yang tidak sedikit.

Tujuan dari penelitian ini adalah mengetahui karakteristik trafik pada pemanfaatan Internet di Pusat Pemerintahan Kabupaten Badung. Terwujudnya pengelolaan atau manajemen bandwidth internet yang lebih baik di Pusat Pemerintahan Kabupaten Badung. Memberikan gambaran umum terhadap user behavior dalam memanfaatkan fasilitas internet yang disediakan oleh Pemerintah Kabupaten Badung. Memberikan masukan kepada pengambil keputusan dalam memanfaatkan dan memanajemen bandwidth.

Koneksi Internet seluruh SKPD di Pusat Pemerintahan Kabupaten Badung dengan kapasitas bandwidth sebesar 200 Mbps, yang dihadapi saat ini adalah keluhan akan stabilitas dan kecepatan akses internet masih banyak terjadi, baik dari internal penggunaan SKPD maupun eksternal dari masyarakat. Permasalahan ini perlu disikapi dengan melakukan analisis mengenai karakteristik trafik pemanfaatan internet dan user behavior di masing-masing SKPD sehingga kebijakan manajemen bandwidth akan tepat sasaran.

I.MD. Rai S. : Analisa Pemanfaatan Internet... 


\section{TINJAUAN PUSTAKA}

Penelitian Pemanfaatan Internet telah banyak dilakukan. Javlonbek Abdujalilov (2014) [2] melakukan pengamatan trafik pada HTTP protocol selama 1 jam pada pukul 10.00 dan pukul 22.00, Dari hasil capture traffic didapatkan informasi bahwa youtobe.com dan vk.me merupakan volume akses terbesar pada kondisi pengamatan. Tristan Henderson dkk. [3], Sama halnya dengan penelitian [4], karena menggunakan SNMP, hanya dapat melihat trafik internet secara umum. Maria Kihl dkk., [5] trafik internet, dapat membantu untuk mengetahui permintaan akses internet saat ini dan akan datang mengingat penggunaan internet yang telah berevolusi dari browsing, file transfer, dan email menjadi multimedia content seperti web $t v$, streaming, dan game online. Karakteristik Penggunaan Internet di Jaringan Area Kampus, Komang Tania Parameswari, Achmad Basuki, Kasyful Amron (2014) [5] monitoring data dengan menggunakan NetFlow sebuah router cisco yang menjadi router utama (core router) dalam suatu jaringan, Dari hasil penelitian didapatkan $88 \%$ trafik digunakan oleh TCP protocol dan $11 \%$ oleh UDP protocol. Metode yang digunakan dalam monitoring jaringan adalah NetFlow. setiap aliran NetFlow yang ditangkap langsung disimpan dalam sebuah data base (mySQL). Penelitian tersebut hanya fokus pada sistem monitoring tanpa adanya pemodelan maupun analasis jaringan [6], [7]. Penelitian Made Andyka dkk. 2016 tentang Analisis trafik dalam 1 bulan, tools yang digunakan adalah PRTG Volume domain didapatkan akses terbesar menuju situs youtube.com, facebook.com [8]. Penelitian [9] melakukan monitoring penggunaan interenet dengan menggunakan tools solarwind yang merupakaan tools berbayar. Penelitian ini bertujuan untuk melakukan analisis untuk memodelkan trafik pengguna. Penelitian [10] menggunakan metode Cacti bekerja berdasarkan SNMP dan pada umumnya hanya dapat melihat akumulasi trafik dari sebuah node atau network, sehingga administrator jaringan tidak dapat melakukan pemilihan trafik berdasarkan penggunaan protocol dan aplikasi serta sumber dan tujuan trafik. Metode Bayes Network menghasilkan klasifikasi trafik jaringan sesuai dengan destination network dan protocol. Dari klasifikasi tersebut terlihat pemakaian dari alamat jaringana tau internet dan protocol jaringan yang paling banyak diakses [11].

\section{Metode Penelitian}

Pengumpulan data penggunaan internet pada jaringan di Pusat Pemerintahan Kabupaten Badung menggunakan aplikasi NetFlow. Aplikasi ini diaktifkan pada Main Router karena dari arsitektur dan topologi jaringan NOC, semua trafik jaringan keluar masuk melalui satu Gateway. Data yang dikumpulkan, dikelompokkan berdasarkan rentang waktu jam kerja, di luar jam kerja, dan hari libur. Gambar 1 merupakan gambaran metode secara umum dari penelitian ini. Fitur traffic flow pada main router diaktifkan dan dikonfigurasi agar data trafik internet yang berasal dari masing-masing workstation terekam pada PC server yang telah terpasang tools NFDUMP. Fungsi dari netflow adalah untuk mengetahui trafik jaringan internet. Sehingga netflow dipasang pada sebuah switch/router core sebagai pusat jalur transmisi trafik dari seluruh user atau client pada jaringan internet. Data hasil pengamatan dengan tool netflow disimpan dan diproses lebih lanjut agar dapat dianalisis.

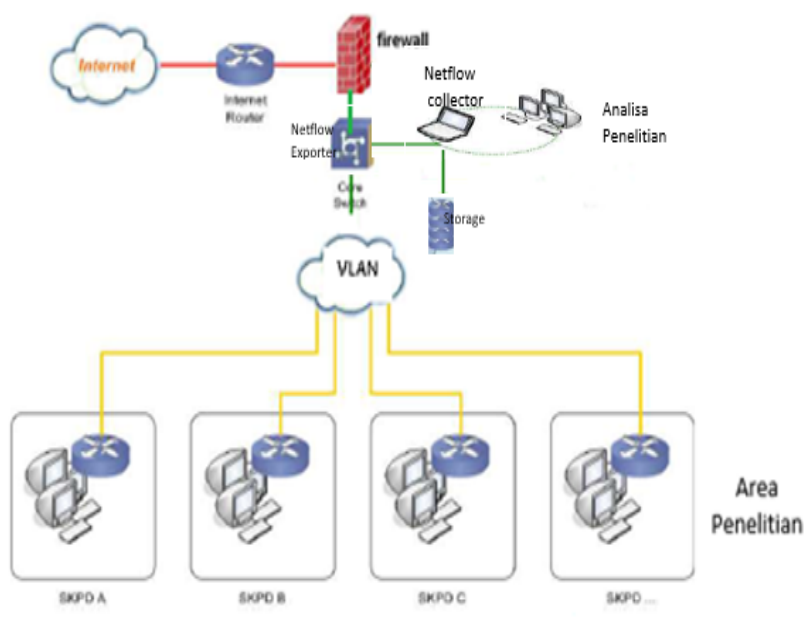

Gambar 1. Monitoring Trafik Internet di Pusat Pemerintahan Kabupaten Badung.

Gambar 2. Kinerja dari konektivitas dari sistem jaringan pada kawasan Pusat Pemerintahan Kabupaten Badung, dimana Dishubkominfo sebagai NOC (Network Operation Centre) dalam pendistribusian bandwidth internet untuk seluruh SKPD, pertukaran sistem dan data melalui media transmisi kabel fiber optik yang menghubungkan perangkat di NOC dengan Distribution Switch (DS) masing-masing unit gedung. Dari DS menggunakan LAN unit gedung berupa kabel UTP menuju Access Switch (AS) yang ada di setiap lantai gedung. Dari AS dihubungkan ke komputer klien seluruh SKPD menggunakan kabel UTP. Switch ini juga merupakan switch pembangkit seluruh vlan yang ada dengan pengalokasian IP pada masing-masing host menggunakan Dynamic Host Configuration Protocol (DHCP). 


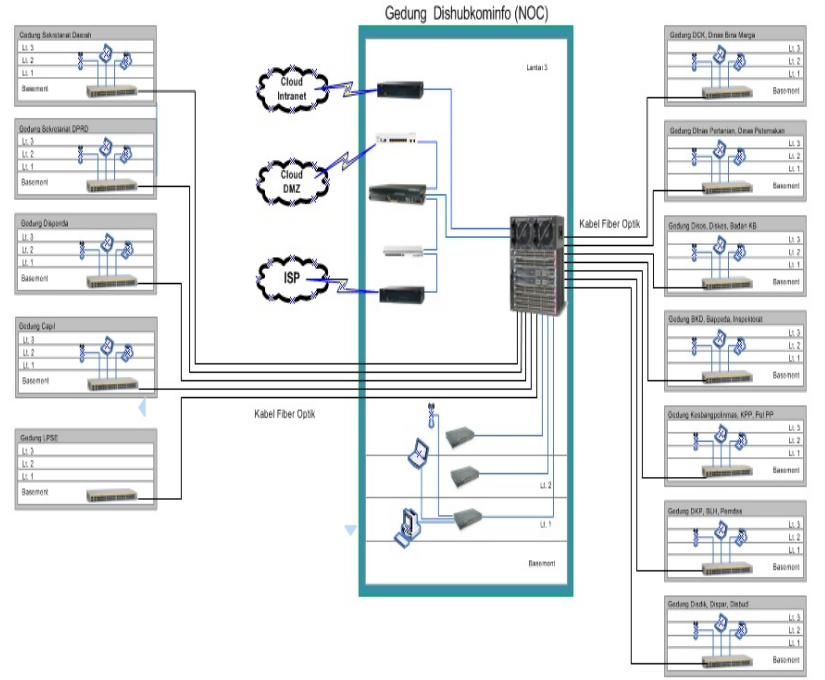

Gambar 2. Arsitektur Jaringan Pusat Pemerintahan Kabupaten Badung.

\section{HASIL DAN PEMBAHASAN}

Hasil yang didapatkan terkait penggunaan protokol aplikasi pada jaringan Pusat Pemerintahan Kabupaten Badung ditampilkan dalam Tabel 4.1 dengan satuan volume (GB). Data pada Tabel 4.1 diambil dari Rata-rata Penggunaan Protokol berdasarkan Volume Trafik, kemudian diambil sample 4 hari Senin, 4 hari Selasa, 4 hari Rabu, dan seterusnya, dari pukul 07.00 sampai dengan pukul 14.00 Tabel 4.1 dan Gambar 4.1 menunjukkan Volume penggunaan protokol di jaringan pemerintah Kabupaten Badung. Protokol TCP mencapai 17,316 GB atau $85 \%$ dari total keseluruhan penggunaan protokol, protokol UDP sebesar 3,081 GB atau $15 \%$, protokol ICMP sebesar 0,62 GB dan protokol lainnya. Berdasarkan Tabel 1 terlihat bahwa total volume trafik (GB) yang digunakan berdasarkan protokolnya. Protokol TCP merupakan protocol tertinggi yang digunakan selama rentang waktu penelitian. Hal ini disebabkan keunggulan dari protocol TCP yang mempunyai proses koreksi kesalahan untuk menjamin proses pengiriman informasi yang lebih handal. Peringkat kedua adalah protokol UDP.

Tabel 1. Kecepatan akases Rata-rata Penggunaan Protokol berdasarkan Volume Trafik

\begin{tabular}{|l|l|l|}
\hline Protokol & $\begin{array}{l}\text { Kecepatan } \\
\text { Akses }(\text { Mbps })\end{array}$ & $\begin{array}{l}\text { Volume } \\
\text { Trafik (GB) }\end{array}$ \\
\hline TCP & $41,299 \mathrm{Mbps}$ & $17,316 \mathrm{~GB}$ \\
\hline UDP & $7,33 \mathrm{Mbps}$ & $3,081 \mathrm{~GB}$ \\
\hline ICMP & $0,14 \mathrm{Mbps}$ & $0,62 \mathrm{~GB}$ \\
\hline OTHER & $0,003 \mathrm{Mbps}$ & $0,0058 \mathrm{~GB}$ \\
\hline
\end{tabular}

\subsection{Trafik TCP}

I.MD. Rai S. : Analisa Pemanfaatan Internet...
Data berdasarkan penggunaan port, khususnya protokol TCP, dapat memberikan gambaran mengenai aplikasi yang banyak digunakan oleh penggunaan Internet di jaringan Pusat Pemerintahan Kabupaten Badung.

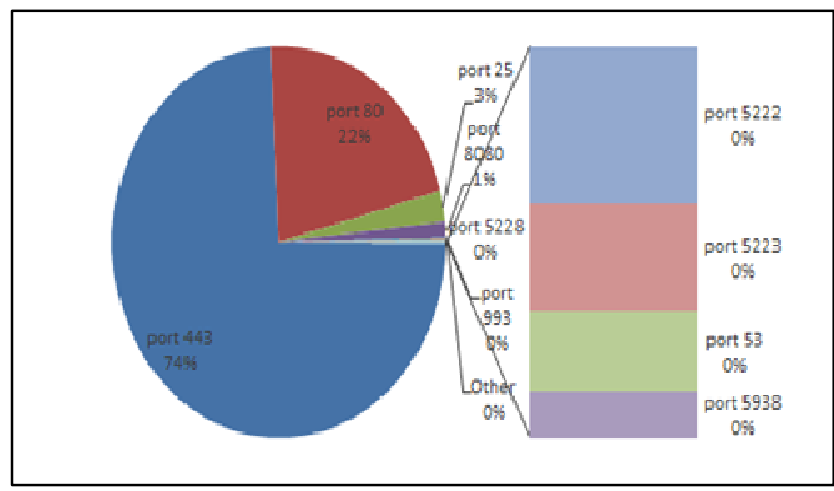

Gambar 3. Kecepatan Akses Rata-rata Protokol TCP BerdasarkanVolume Trafik (GB)

Perbedaan warna pada diagram menunjukkan perbedaan port pada masing-masing bagiannya. Warna biru ditujukan untuk port 443 (https), warna merah tua ditujukan untuk port 80 atau http, warna hijau ditujukan untuk port 25, sisa dari itu dikelompokkan menjadi others port yang penggunaannya sangat kecil sehingga tidak muncul dalam diagram pie. Other's port dapat ditunjukkan dengan port 5222, port 5223, port 53, dan port 5938.

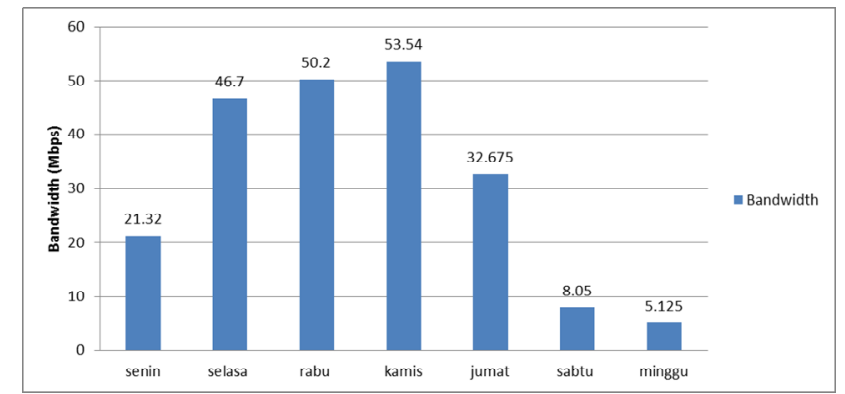

Gambar 4. Kecepatan Akses Rata-rata Protokol TCP

Kecepatan rata-rata akses yg didapat selama waktu pengamatan untuk hari senin adalah sebesar 21,32 Mbps, hari Selasa akses meningkat menjadi 46,7 Mbps, hari Rabu menjadi 50,2 Mbps, dan pada hari Kamis, tertinggi sebesar 53,54 Mbps, sedangkan pada hari Jumat akses menurun, menjadi 20,87 Mbps. Selanjutnya pada akhir pekan kecepatan akses rata-rata kecepatan akses menurun menjadi 8,05 Mbps pada hari sabtu dan 5,125 Mbps pada hari minggu. 


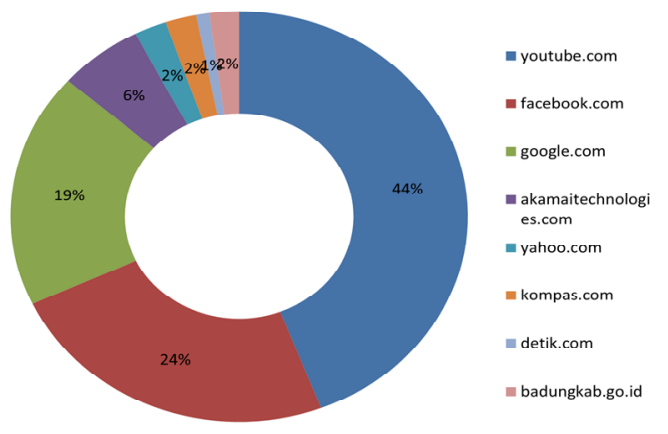

Gambar 5. Kategori Aplikasi berdasarkan Protokol TCP (GB)
Akses tertinggi pada Pusat Pemerintahan Kabupaten Badung adalah Youtube, yaitu 44\% dari total keseluruhan penggunaan Internet. Selanjutnya $24 \%$ adalah menuju Facebook.com yang merupakan situs sosial media. Trafik menuju Google Inc, merupakan situs pencarian, sebesar $19 \%$. Selanjutnya, 6\% trafik ke arah Akamai sebagai bagian jaringan CDN globalnya, merupakan infrastruktur (backbone) jaringan Internet. Banyak (Internet Service Provider) ISP, operator telekomunikasi, dan data center. Sebut contoh Telkom, Telkomsel, Biznet, Smartfren, Indosat Ooredoo, XL Axiata, LinkNet (FirstMedia), Tri, Lintas Arta, MNC menggunakan backbone ini.

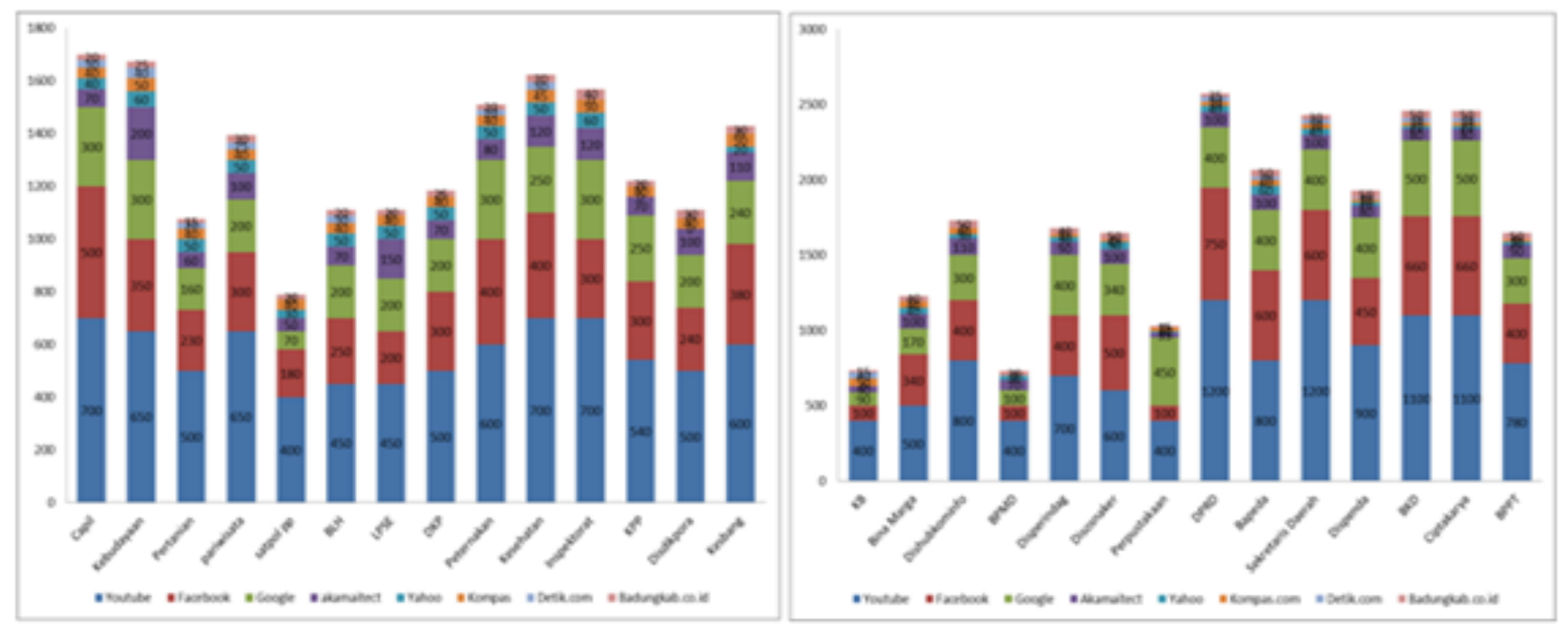

Gambar 6. Penggunaan Akses Situs di Seluruh SKPD di Kabupaten Badung
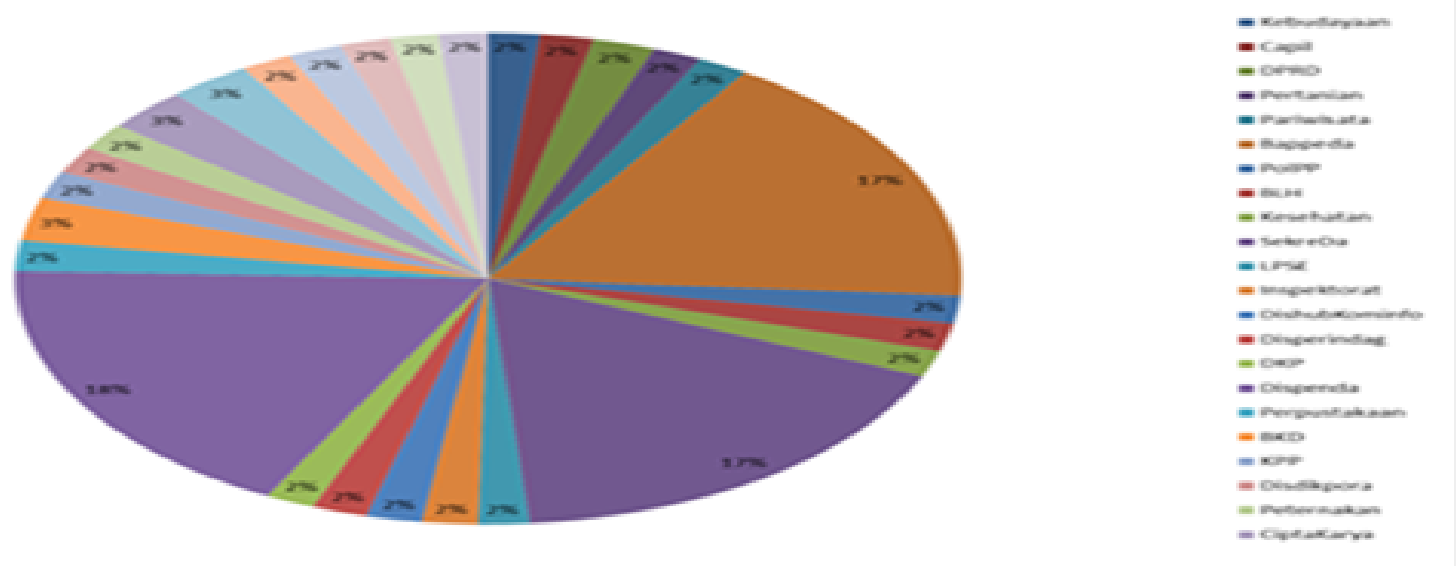

Gambar 7. Prosentase Penggunaan Internet Berdasarkan SKPD di Kabupaten Badung

ISSN 1693-2951; e-ISSN: 2503-2372 I.MD.Rai S. : Analisa Pemanfaatan Internet... 
Dari pembahasan penggunaan TCP di masing-masing SKPD menunjukkan bahwa pengguna terbesar untuk mengakses 3 situs yang mendominasi penggunaan trafik di Pemerintah Kabupaten Badung adalah Sekretariat Daerah, disusul oleh Dispenda dan Bappeda Hasil selengkapnya ditunjukkan pada tabel.

Tabel 2. Penggunaan 3 situs yang mendominasi pada pengguna trafik

\begin{tabular}{|c|c|c|c|c|}
\hline No & SKPD & Youtube & Facebook & Google \\
\hline 1 & Sekretariat Daerah & $47 \%$ & $28 \%$ & $16 \%$ \\
\hline 2 & Dispenda & $45 \%$ & $26 \%$ & $20 \%$ \\
\hline 3 & Bappeda & $37 \%$ & $32 \%$ & $18 \%$ \\
\hline
\end{tabular}

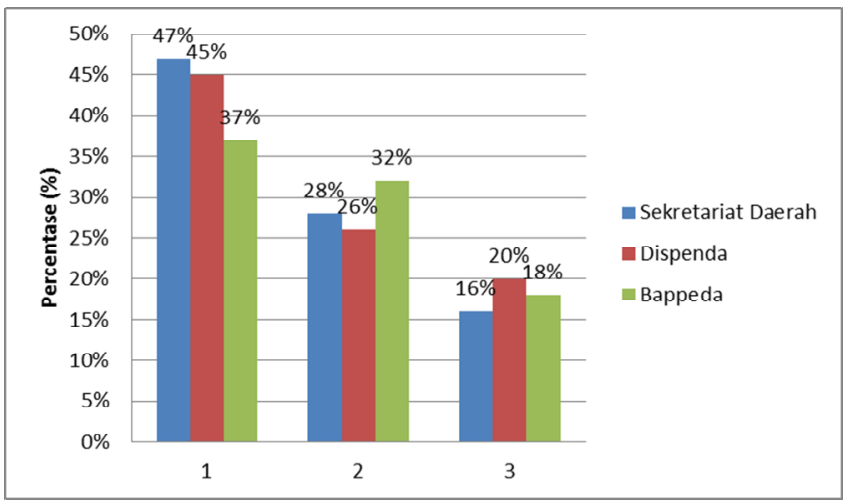

Gambar 8. Penggunaan 3 situs yang mendominasi pada pengguna trafik

\subsection{Trafik UDP}

Hasil dari data terkait penggunaan port berdasarkan protokol UDP dapat memberikan Gambaran mengenai aplikasi yang dominan digunakan oleh pengguna Internet pada jaringan Pusat Pemerintahan Kabupaten Badung. Pada Gambar 9. Pusat Pemerintahan Kabupaten Badung dari protokol UDP berdasarkan volume trafik.

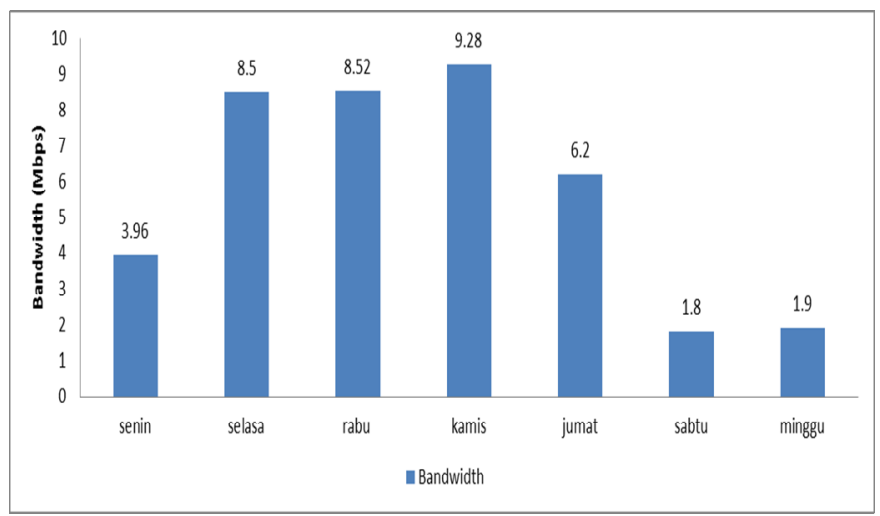

Gambar 9. Kecepatan Akses rata-rata Protokol UDP
Gambar 10. Menjelaskan bahwa rata-rata kecepatan akses protokol UDP pada jam sibuk memiliki pola yang hampir sama dengan penggunaan protokol TCP. Namun penurunan berbeda pada kedua protokol itu terjadi dari hari kerja menuju hari libur. Penurunan protokol UDP sebesar lebih dari $80 \%$ dari rata-rata kecepatan akses pada hari kerja, dari 36,76 Mbps menjadi 3,7 Mbps pada hari libur.

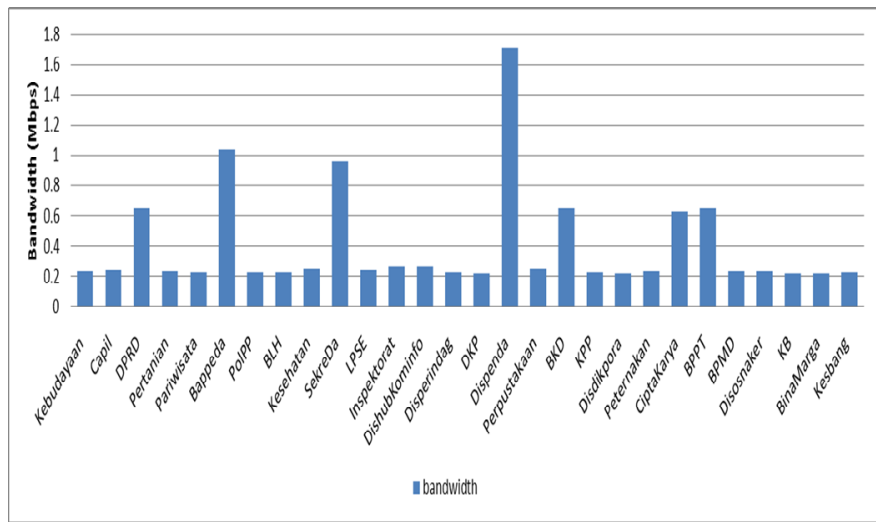

Gambar 10. Kecepatan Akses rata-rata Penggunaan Internet

Gambar 11. Menunjukkan grafik rata-rata penggunaan Internet secara keseluruhan (total), baik hari kerja dan hari libur menunjukkan terdapat pola akses penggunaan Internet pada jam-jam tertentu. Penggunaan Internet meningkat pada hampir di jam yang sama di tiap harinya. Pada jam sibuk (peak time) terlihat bahwa bandwidth yang digunakan sangat tinggi dan karakteristik penggunaan lebih mencerminkan keadaan sesungguhnya karena sebagian besar user aktif pada jam-jam sibuk.

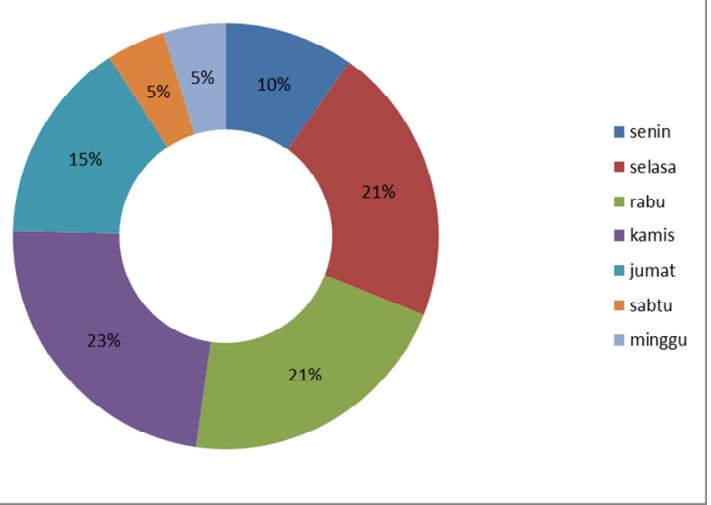

Gambar 11. Diagram Kecepatan Akses Protokol UDP

Untuk penggunaan UDP diketahui bahwa SKPD pengguna terbesar yang mendominasi penggunaan trafik di Pemerintah Kabupaten Badung sebagai berikut :

I.MD. Rai S. : Analisa Pemanfaatan Internet...

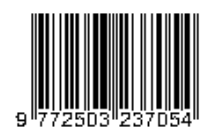


Tabel 3 Pengguna terbesar mengakses port melalui protokol UDP

\begin{tabular}{|c|c|c|c|}
\hline No & SKPD & Port 80 & Port 443 \\
\hline 1 & Sekretariat Daerah & $5.91 \%$ & $84.09 \%$ \\
\hline 2 & Dispenda & $45.80 \%$ & $45 \%$ \\
\hline 4 & Bappeda & $5.34 \%$ & $85.30 \%$ \\
\hline
\end{tabular}

4.3 Penggunaan Internet di masing-masing SKPD

Gambar 7. Menunjukkan diagram pie persentase penggunaan masing-masing SKPD pada hari kerja dan hari libur yang menuju jaringan Pusat Pemerintahan Kabupaten Badung. Disini terlihat bahwa penggunaan pada Dispenda (16\%) mendominasi diantara jaringan kabel lainnya diikuti dengan penggunaan di area Gedung Sekretaris Daerah (15\%), dan Bappeda sebesar (15\%) dan yang lainnya.

Pada masing-masing SKPD memiliki persentase tidak lebih dari 5\%., ini menunjukan bahwa hanya 3 SKPD yang penggunaan internet yang mendominasi. Sehingga bandwidth terbesar berada pada 3 SKPD tersebut.

\section{KESIMPULAN}

Penelitian ini menunjukan bahwa Karakteristik pengguna Internet di Pemerintah Kabupaten Badung terdiri dari $85 \%$ protokol TCP, 15\%UDP, dan 5\% protokol ICMP dan other protocol. Kecepetan akses ratarata pada jam sibuk hari Senin agak rendah, meningkat pada hari Selasa hingga Kamis, sedangkan hari Jumat menurun kembali sebesar $23 \%$ terhadap hari Kamis. Penurunan penggunaan pada hari Sabtu dan Minggu cukup signifikan, yaitu sebesar $60 \%$, jika dibandingkan terhadap hari kerja karena hari Sabtu dan Minggu pegawai tidak bekerja. Dari pembahasan Pola akses TCP di masing-masing SKPD menunjukkan bahwa peringkat trafik tertinggi untuk 3 situs adalah Youtube, Faebook, dan Google. Lebih detail yaitu, Untuk Sekretariat Daerah,Youtube $47 \%$, Facebook 28\%, dan Google 16\%. Sedangkan Dispenda dengan komposisi Youtube 45\%, Facebook 26\%, dan Google 20\%. Selanjutnya, di Bappeda persentase Youtube $37 \%$, Facebook 32\%, dan Google 18\%.Terlihat bahwa penggunaan Internet di seluruh SKPD lebih banyak mengakses youtube dan facebook.

Tidak adanya pengaturan bandwidth meyebabkan terjadinya keluhan akses yang lambat dari 28 SKPD. Lambatnya akses internet pada setiap SKPD karena banyaknya pengguna yang mengakses internet dan tidak adanya aturan terkait penggunaan internet, baik dari prioritas, kecepatan dan hal lain.

\section{REFRENSI}

[1] Instruksi Presiden Republik Indonesia Nomor 3 Tahun 2003 tentang Kebijakan dan Strategi Nasional Pengembangan E-Government.
[2] Javlonbek, Abdujalilov. "Popularity Of Websites: HTTP Traffic Analysis". Asian Journal of Computer and Information Systems. (AJCIS) ISSN: 2321 - 5658, 2014

[3] Henderson, Tristan, David Kotz, and Ilya Abyzov. "The changing usage of a mature campus-wide wireless network." Computer Networks 52, no. 14 (2008): 26902712.

[4] Gebert, Steffen. Pries,Rastin. Schlosser, Daniel, Heck, Klaus. "Internet Access Traffic Measurement and Analysis". Austria: PAM, 2012.

[5] Kihl, Maria, Per Ödling, Christina Lagerstedt, and Andreas Aurelius."Traffic analysis and characterization of Internet user behavior." InUltra Modern Telecommunications and Control Systems and Workshops (ICUMT), 2010 International Congress on, pp. 224-231.IEEE, 2010.'

[6] Paramecwari, Komang Tania. Basuki, Achmad. Amron, Kasyful."Karakteristik Penggunaan Internet di Jaringan Area Kampus (Studi Kasus: PTIIK Universitas Brawijaya)". Doro Jurnal Volume 3, No. 12, 2014.

[7] Made Bayu Dibawan, Made Oka Widyantara, Linawat. "Klasifikasi Trafik Internet Kampus Berbasis Protokol Jaringan Menggunakan "Algoritma Nä̈ve Bayes". Vol 2, No. 3, 2016.

[8] Made Andyka Surya Kencana, Linawati, I Made Oka Widyantara 2016 Analisis Pemanfaatan Internet di Pemerintah Kota Denpasar Studi Kasus : Dinas Perijinan ISSN 1693 - 2951; e-ISSN: 2503-2372 Teknologi Elektro, Vol. 15, No. 2, 2016.

[9] Kassim, Murizah, Mahamod Ismail, and Mat Ikram Yusof. "Statistical analysis and modeling of internet traffic IP-based network for teletraffic engineering." ARPN Journal of Engineering and Applied Sciences 10, no. 3 (2015): 1505

[10] Agung Distiana, "Karakterisasi Trafik Universitas Udayana menggunakan Protokol SNMP”,Vol. 3 No. 2 2015

[11] R. Prathivi, Klasifikasi Data Trafik Internet Menggunakan Metode Bayes Network (Studi Kasus Jaringan Internet Universitas Semarang), J. Tr NsForMat Ka , vol. 12, no. 2, Januari 2015 